\title{
Benzimidazole inhibitors of protein kinase CK2 potently inhibit the activity of atypical protein kinase Rio1
}

\author{
Konrad Kubiński $^{1} \cdot$ Maciej Masłyk $^{1} \cdot$ Andrzej Orzeszko $^{2}$
}

Received: 2 September 2016/Accepted: 25 November 2016/Published online: 1 December 2016

(C) The Author(s) 2016. This article is published with open access at Springerlink.com

\begin{abstract}
Benzimidazole derivatives of 5,6-dichlorobenzimidazole 1- $\beta$-D-ribofuranoside (DRB) comprise the important class of protein kinase CK2 inhibitors. Depending on the structure, benzimidazoles inhibit CK2 with different selectivity and potency. Besides CK2, the compounds can inhibit, with similar activity, other classical eukaryotic protein kinases (e.g. PIM, DYRK, and PKD). The present results show that a majority of the most common CK2 inhibitors can affect the atypical kinase Rio1 in a nanomolar range. Kinetic data confirmed the mode of action of benzimidazoles as typical ATP-competitive inhibitors. In contrast to toyocamycin-the first discovered small-molecule inhibitor of Rio1-the most potent representative of benzimidazoles TIBI $\left(\mathrm{IC}_{50}=0.09 \mu \mathrm{M}\right.$, $\left.K_{i}=0.05 \mu \mathrm{M}\right)$ does not influence the oligomeric state of the Rio1 kinase. Docking studies revealed that TIBI can occupy the ATP-binding site of Rio1 in a manner similar to toyocamycin, and enhances the thermostability of the enzyme.
\end{abstract}

Keywords Protein kinases - Small-molecule inhibitors · Competitive inhibition · Toyocamycin · TIBI

Maciej Masłyk

maciekm@kul.pl

1 Department of Molecular Biology, Institute of Biotechnology, The John Paul II Catholic University of Lublin, ul. Konstantynów 1i, 20-708 Lublin, Poland

2 Institute of Chemistry, Warsaw Life Sciences University, ul. Nowoursynowska 159c, 02-787 Warsaw, Poland

\section{Introduction}

Protein kinases play important roles in key cellular processes, including the cell cycle, metabolism, and cell death $[1,2]$. The protein kinase superfamily, with 518 members, comprises one of the largest protein superfamilies identified in the human genome [3]. In addition to their key roles in cell physiology, about half of protein kinases are linked to pathological states, including cancer $[4,5]$. This fact makes kinases attractive targets for therapeutic intervention.

One such kinase therapeutic target is probably the most pleiotropic protein kinase, CK2. It phosphorylates more than 300 protein substrates and thus remarkably increases the level of total protein phosphorylation in the cell $[6,7]$. Interestingly, the enzyme is constitutively active, and the mode of its on/off mechanism is unknown [7, 8]. The plethora of cellular partners makes protein kinase CK2 engaged in a majority of cellular processes, both physiological, such as the cell cycle, and pathological ones, e.g. viral infection or cancer development [9]. Elevated expression and activity levels of CK2 have been reported in many human pathologies, including cancer cells (reviewed in [10]).

Benzimidazole derivatives represent the biggest family of ATP-competitive inhibitors of protein kinase CK2, with a scaffold derived from the 5,6-dichloro-1-( $\beta$-D-ribofuranosyl)benzimidazole (DRB) molecule [11]. Starting from this molecule, the structure of the inhibitors has been optimized to better fit in the ATP-binding pocket [12]. In this respect, the most successful commercially available benzimidazole CK2 inhibitors are TBB, TBI, and DMAT [13]. Benzimidazole derivatives effectively inhibit both native and recombinant CK2 activity in vitro and in cell culture showing proapoptotic properties [14, 15]. Although benzimidazole derivatives are potent inhibitors of CK2, TBB, TBI, and even the most selective DMAT show 
activity towards several other kinases, such as PIM, DYRK, or PKD [13].

The protein kinase superfamily includes 40 members that are classified as atypical protein kinases. One such enzyme is the Riol kinase, the founding member of the RIO family that also comprises Rio2, Rio3, and RioB $[16,17]$. Rio1 is involved in ribosome biogenesis, cell cycle progression, and chromosome maintenance [18-20]. Studies on yeast revealed that Rio1 is a non-ribosomal factor that is essential for the processing of $20 \mathrm{~S}$ pre-rRNA to $18 \mathrm{~S}$ rRNA, a component of the $40 \mathrm{~S}$ subunit $[21,22]$. Little is known about the physiological role of Rio1-mediated phosphorylation, cellular protein substrates of the enzyme, and the physiological role of Rio1 autophosphorylation. Although the possible role of Rio1 in pathogenesis is not well established in comparison to many other kinases, it was reported that the enzyme is upregulated in colon cancer, and there is a direct link between deregulation of ribosome biogenesis and tumour development [23]. In other studies, Read and coworkers showed that the kinases Rio1 and Rio2 are overexpressed in glioblastoma cells in an Akt-dependent manner and promote tumorigenesis [24].

Toyocamycin was the first identified small-molecule inhibitor of Rio1, showing mixed inhibition. This mode of action of toyocamycin results from its dual activity towards the Rio1 kinase. On the one hand, toyocamycin acts as an ATP-competitive inhibitor, and on the other hand, it stabilizes the less catalytically active oligomeric isoform of the Rio1 kinase [25]. Recently, several pyridine caffeic acid benzyl amides (CABA) have been identified as a novel molecular probes of the Riol following the ATP-competitive inhibition mode [26].

Here we present a series of benzimidazole CK2 inhibitors as novel synthetic small-molecule inhibitors of the Rio1 kinase. We analysed the kinetic data of Rio1 autophosphorylation in the presence of the most active compound TIBI, with respect to the inhibition model. In order to verify the influence of TIBI on the thermostability of human Rio1, we determined the melting temperature of the enzyme in the presence and absence of the inhibitor. We also employed size-exclusion chromatography to validate whether TIBI is able to affect the oligomeric state of Rio1. Moreover, computational studies were used in order to calculate possible kinase-ligand complexes.

\section{Materials and methods}

\section{Reagents and benzimidazole CK2 inhibitors}

All reagents were purchased from Sigma-Aldrich. 4,5,6,7Tetrabromo-2-azabenzimidazole, (TBB), 2-dimethylamino-4,5,6,7-tetrabromobenzimidazole (DMAT), and toyocamycin were purchased from Sigma-Aldrich. CX4945 (Silmitasertib) was purchased from APEXBIO. All the other benzimidazoles studied were synthesized in our laboratory previously and have already been described as follows:

TIBI, (4,5,6,7-tetraiodobenzimidazole) [27].

K92, (4,5,6,7-tetraiodo-2-methylbenzimidazole), [27].

$T I-2 A m, \quad(4,5,6,7$-tetraiodobenzimidazole-2-amine-ethylamine), [28].

TidiMe, (2-dimethylamino-1-metyl-4,5,6,7-tetraiodobenzimidazole), [28].

K95, (4,6-dibromo-5,7-diiodobenzimidazole), [27].

TBI (4,5,6,7-tetrabromobenzimidazole), [29].

TCI, (4,5,6,7-tetrachlorobenzimidazole), [30].

$T D B B$ (3-methyl-4-[4,5,6,7-tetrabromo-2-(dimethylamino) benzimidazole-1-yl]butanoic acid, [31].

$T B S B$, (3-(4,5,6,7-tetrabromobenzimidazole-2-yl sulfanyl) butanoic acid), [31].

IMe-DMAT, (4,5,6,7-tetrabromo- $N, N, 1$-trimethylbenzimidazole-2-amine), [12].

TBTS, [(4,5,6,7-tetrabromo- $N, N, 1$-trimethylbenzimidazole-2-yl)sulfanyl]acetic acid, [31].

\section{Kinase activity assays}

Recombinant human protein kinase GST-CK2 $\alpha$ was produced in bacteria and purified as described elsewhere [32]. The plasmid carrying the gene encoding human protein kinase Rio1 (residues 143-494) was kindly gifted by Professor Nicole LaRonde-LeBlanc (University of Maryland, USA). Human recombinant kinase Rio1 containing residues 134-494 was expressed and purified as previously reported with a few modifications [33].

In the case of CK2, the phosphorylation reactions were conducted at $37{ }^{\circ} \mathrm{C}$ for $5 \mathrm{~min}$ in $50 \mu \mathrm{l}$ samples each containing 1 pmol of human recombinant CK2 $\alpha, 10 \mu \mathrm{g}$ of ribosomal $\mathrm{P} 2 \mathrm{~B}$ protein as a substrate, and an appropriate concentration of the tested benzimidazole $(0.01-50 \mu \mathrm{M})$. The reaction buffer contained $20 \mu \mathrm{M}\left[\gamma-{ }^{32} \mathrm{P}\right] \mathrm{ATP}$ (specific radioactivity $300-1000 \mathrm{cpm} / \mathrm{pmol}$ ), $15 \mathrm{mM} \mathrm{Mg}{ }^{2+}, 20 \mathrm{mM}$ Tris- $\mathrm{HCl} \mathrm{pH} \mathrm{7.5,} \mathrm{and} 6 \mathrm{mM}$ 2-mercaptoethanol.

In order to determine the autophosphorylation of human Rio1, the enzyme was incubated at $37{ }^{\circ} \mathrm{C}$ for $15 \mathrm{~min}$ in $50 \mu \mathrm{l}$ samples each containing $1 \mathrm{pmol}$ of human recombinant Rio1 and an appropriate concentration of tested compound $(0.01-50 \mu \mathrm{M})$. The reaction buffer contained $0.5 \mu \mathrm{M}$ ATP, $\left[\gamma_{-}{ }^{32} \mathrm{P}\right] \mathrm{ATP}$ (specific radioactivity $300-1000 \mathrm{cpm} / \mathrm{pmol}), \quad 50 \mathrm{mM} \mathrm{NaCl}, \quad 10 \mathrm{mM} \mathrm{Mg}^{2+}$,

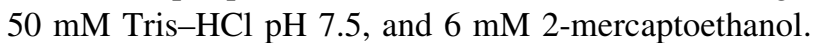

In order to determine the $K_{\mathrm{m}}$ of Rio1 for ATP, Rio1 was incubated for $5 \mathrm{~min}$ in the presence of increasing concentrations of ATP $(0.001-1 \mu \mathrm{M})$ in a reaction buffer 
containing $50 \mathrm{mM} \mathrm{NaCl}, 10 \mathrm{mM} \mathrm{Mg}{ }^{2+}, 50 \mathrm{mM}$ Tris- $\mathrm{HCl}$ $\mathrm{pH} 7.5,6 \mathrm{mM}$ 2-mercaptoethanol, and $1 \mu \mathrm{Ci}$ of $\left[\gamma_{-}{ }^{32} \mathrm{P}\right]$ ATP. Additionally, the same protocol was followed with the addition of TIBI to the reaction mixture at a concentration of $0.01,0.05$, and $0.1 \mu \mathrm{M}$. The use of such low concentrations of ATP in reaction mixtures was optimal for Rio1, and resulted from the inhibition of Rio1 activity at ATP concentration greater than $1 \mu \mathrm{M}[25,26]$.

The phosphorylation was terminated by addition of SDS/PAGE sample buffer, and proteins were resolved by electrophoresis, followed by Coomassie Brilliant Blue staining. The gels were dried and ${ }^{32} \mathrm{P}$-labelled bands of $\mathrm{P} 2 \mathrm{~B}$ and Riol were excised from the gel, and radioactivity was determined in a scintillation counter (MicroBeta, Perkin Elmer) by Cerenkov counting.

Kinetic data were obtained using enzyme preparations from three purification batches.

All experiments were performed in triplicate.

$\mathrm{IC}_{50}, K_{i}, K_{\mathrm{m}}$, and $V_{\max }$ values were calculated using GraphPad Prism (version 4.0) software.

\section{Thermofluor assay}

The procedure was performed according to the protocol described elsewhere with a few modifications [25]. 10- $\mu$ l reactions containing $50 \mathrm{mM} \mathrm{NaCl}, 10 \mathrm{mM} \mathrm{Mg}^{2+}, 50 \mathrm{mM}$ Tris-HCl pH 7.5, $1 \mathrm{mg} / \mathrm{ml}$ hRiol or hCK2 $\alpha$, and $100 \mu \mathrm{M}$ TIBI or $5 \%$ DMSO (control) were incubated at $4{ }^{\circ} \mathrm{C}$ for $30 \mathrm{~min} .10 \mu \mathrm{l}$ of the SYPRO Orange dye was then added to the reactions. The samples were heated from 4 to $98{ }^{\circ} \mathrm{C}$ at a rate of $0.2^{\circ}$ per second using a thermal cycler (CFX 1000, Bio-Rad). The changes in fluorescence intensity were measured as the temperature increased. Melting temperatures $\left(T_{\mathrm{m}}\right)$ of hRio1 and CK2 in the presence and absence of TIBI were calculated using Bio-Rad software. The experiment was performed in duplicate.

\section{Size-exclusion chromatography}

The glass column $(200 / 10 \mathrm{~mm})$ filled with the Sephadex G-200 medium (GE Healthcare) was equilibrated with a buffer containing $10 \mathrm{mM}$ Tris, $\mathrm{pH} 7.5,150 \mathrm{mM} \mathrm{NaCl}$, and $6 \mathrm{mM} \beta$-mercaptoethanol. In order to calibrate the column, four proteins, namely $\beta$-amylase $(200 \mathrm{kDa})$, alcohol dehydrogenase $(150 \mathrm{kDa})$, bovine serum albumin $(67 \mathrm{kDa})$, and ovalbumin (43 kDa), were separately loaded onto the column. 100- $\mu \mathrm{l}$ samples containing $2 \mathrm{mg} / \mathrm{ml}$ hRio1 diluted in the equilibration buffer in the presence or absence (control) of $100 \mu \mathrm{M}$ TIBI were then loaded onto the column. The chromatography was performed at a flow rate $0.2 \mathrm{ml} / \mathrm{min}$ using the FPLC system AKTA Purifier 10 (GE Healthcare), and runs were monitored by $\mathrm{OD}_{280}$.

\section{Computational studies}

For molecular docking, we selected the X-ray structure of CK2 in complex with ANP (PDB ID: 3NSZ) and Rio1 in complex with ADP (PDB ID: 4OTP) as target proteins for the initial docking studies. All $\mathrm{Mg}^{2+}$ ions were removed in the $3 \mathrm{NSZ}$ and 4OTP experimental structures as well as all sulphates, co-solvents, water molecules, and original ligands. The structures were then minimized using YASARA Energy Minimization Server [34]. Autodock Tools v1.5.6 (The Scripps Research Institute) was used for charging the proteins as well as ligands. Docking calculations were performed with Autodock Vina v1.1.2 (The Scripps Research Institute) under default conditions [35]. During the docking calculations, all the protein residues were fixed and only the inhibitor atoms were allowed to move. Visualization of the binding site complexed with the docked ligand was performed by Maestro Suite and PyMOL v1.2 (Schrödinger) software.

\section{Results and discussion}

\section{Benzimidazole inhibitors of protein kinase CK2 suppress the autophosphorylation of an atypical human kinase Rio1}

Halogenated benzimidazoles are widely reported as CK2 inhibitors that (i) downregulate both native and recombinant protein kinases CK2 from various sources [36], (ii) can discriminate between different isoforms of the enzyme in vitro [31,37], (iii) induce apoptosis in many cancer cell lines [38, 39], and (iv) can inhibit other classical eukaryotic protein kinases with different potency [13]. Our results show that the atypical protein kinase (the most stable form of Rio1 containing residues 134-494) is susceptible to benzimidazole inhibitors of CK2 (Table 1). With the exception of TDBB, TCI, and TBB, the tested compounds suppress the autophosphorylation of the Riol kinase in a nanomolar range. Although TBB inhibits CK2 ca. 10 times more strongly $\left(\mathrm{IC}_{50}=0.19 \mu \mathrm{M}, K_{i}=0.081 \mu \mathrm{M}\right)$ than Rio1 $\left(\mathrm{IC}_{50}=1.74 \mu \mathrm{M}, K_{i}=0.983 \mu \mathrm{M}\right)$, the atypical kinase belongs, together with Pim1 and Pim3, to the most sensitive kinases to TBB action [13]. TCI displays the least efficacy towards the two tested kinases, which is consistent with previous reports showing that chloride derivatives of benzimidazoles are not as efficient CK2 inhibitors as other halogenated derivatives [36]. The majority of the other nanomolar inhibitors behave more similarly against CK2 and Rio1 with a slight advantage of the former one. The inhibition of CK2 by TI-2Am was ca. sixfold stronger than that of Rio1. In turn, K92 induced fourfold stronger inhibition of CK2 than that of Rio1, and in the case of 1Me- 
Table $1 \mathrm{IC}_{50}$ and $\mathrm{K}_{\mathrm{i}}$ determinations for benzimidazole derivatives against protein kinases Rio1 and CK2

\begin{tabular}{|c|c|c|c|c|c|}
\hline \multirow[t]{2}{*}{ Inhibitor } & \multirow[t]{2}{*}{ Structure } & \multicolumn{2}{|c|}{$\mathrm{IC}_{50}(\mu \mathrm{M}) \pm \mathrm{SD}$} & \multicolumn{2}{|l|}{$\mathrm{K}_{\mathrm{i}}(\mu \mathrm{M}) \pm \mathrm{SD}$} \\
\hline & & Rio1 & CK2 & Rio1 & CK2 \\
\hline TIBI & & $0.09 \pm 0.005$ & $0.083 \pm 0.003$ & $0.05 \pm 0.002$ & $0.035 \pm 0.001$ \\
\hline K92 & & $0.19 \pm 0.011$ & $0.066 \pm 0.003$ & $0.1 \pm 0.004$ & $0.025 \pm 0.001$ \\
\hline DMAT & $\mathrm{Br}$ & $0.19 \pm 0.009$ & $0.19 \pm 0.008$ & $0.1 \pm 0,003$ & $0.081 \pm 0.003$ \\
\hline TI-2Am & & $0.23 \pm 0.01$ & $0.050 \pm 0.002$ & $0.13 \pm 0.005$ & $0.021 \pm 0.001$ \\
\hline TIdiMe & & $0.24 \pm 0.008$ & $0.20 \pm 0.006$ & $0.135 \pm 0.005$ & $0.085 \pm 0.003$ \\
\hline K95 & & $0.29 \pm 0.009$ & $0.30 \pm 0.009$ & $0.164 \pm 0.007$ & $0.128 \pm 0.005$ \\
\hline TBI & & $0.33 \pm 0.007$ & $0.44 \pm 0.01$ & $0.186 \pm 0.009$ & $0.188 \pm 0.007$ \\
\hline 1Me-DMAT & & $0.61 \pm 0.02$ & $0.39 \pm 0.012$ & $0,344 \pm 0.011$ & $0.167 \pm 0,009$ \\
\hline
\end{tabular}


Table 1 continued

Inhibitor Structure

TBTS<smiles>Cn1c(SCC(=O)O)nc2c(Br)c(Br)c(Br)c(Br)c21</smiles>
$0.69 \pm 0 ., 2$
$0.60 \pm 0.03$
$0.39 \pm 0.011$
$0.257 \pm 0.009$

TBB<smiles>Brc1c(Br)c(Br)c2[nH]nnc2c1Br</smiles>

TCI<smiles>Clc1c(Cl)c(Cl)c2[nH]cnc2c1Cl</smiles>
$1.9 \pm 0.07$
$9.7 \pm 0.3$
$1.07 \pm 0.04$
$4.15 \pm 0.1$

TDBB<smiles>CCn1c(N(C)C)nc2c(Br)c(Br)c(Br)c(Br)c21</smiles>

Reference compounds<smiles>N#Cc1cn(C2OC(CO)C(O)C2O)c2ncnc(N)c12</smiles>

CX-4945

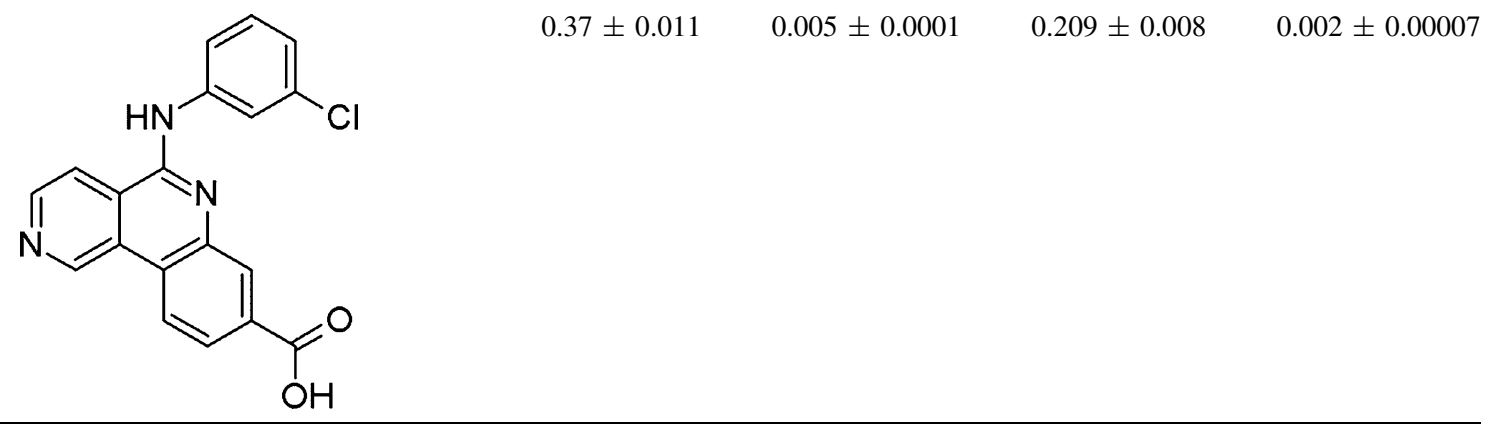

$\begin{array}{llll}3.66 \pm 0.09 & 54.78 \pm 1.9 & 2.068 \pm 0.07 & 23.47 \pm 0.8\end{array}$

$23.47 \pm 0.8$

$\begin{array}{llll}2.17 \pm 0.06 & 1.51 \pm 0.04 & 1.226 \pm 0.03 & 0.647 \pm 0.014\end{array}$

\begin{tabular}{lllll}
$\mathrm{IC}_{50}(\mu \mathrm{M}) \pm \mathrm{SD}$ & & & $\mathrm{K}_{\mathrm{i}}(\mu \mathrm{M}) \pm \mathrm{SD}$ & \\
\cline { 1 - 2 } \cline { 5 - 6 } Rio1 & $\mathrm{CK} 2$ & & Rio1 & CK2 \\
\hline $0.65 \pm 0.03$ & $0.33 \pm 0.013$ & & $0.367 \pm 0.012$ & $0.141 \pm 0.005$
\end{tabular}

$1.74 \pm 0.05$

$0.19 \pm 0,007$

$0.983 \pm 0.03$

$0.081 \pm 0.002$ 
DMAT and TBSB, the inhibition of CK2 was twofold stronger than that of Rio1. The other compounds showed almost the same efficacy towards both kinases, and TIBI with $\mathrm{IC}_{50}=0.09 \mu \mathrm{M}$ and $K_{i}=0.05 \mu \mathrm{M}$ appeared to be the most potent inhibitor of Rio1. We observed that higher potency towards the atypical kinase was shown by the iodine derivatives of benzimidazole $\left(\mathrm{IC}_{50}\right.$ between 0.09 and $0.24 \mu \mathrm{M}, K_{i}$ values between 0.05 and $0.135 \mu \mathrm{M}$ ) than by the bromide derivatives $\left(\mathrm{IC}_{50}\right.$ between 0.19 and $2.17 \mu \mathrm{M}, K_{i}$ values between 0.1 and $1.226 \mu \mathrm{M}$ ), with no significant changes caused by the addition of methyl (K92, TIdiMe) or amino groups (TI-2Am). One of the most potent inhibitors of Rio1 is the commercially available DMAT $\left(\mathrm{IC}_{50}=0.19 \mu \mathrm{M}, K_{i}=0.1 \mu \mathrm{M}\right)$, which appeared to be not as selective towards CK2 $\left(\mathrm{IC}_{50}=0.19 \mu \mathrm{M}\right.$, $\left.K_{i}=0.081 \mu \mathrm{M}\right)$ as TBB, which is consistent with data presented previously by Pagano and coworkers [13]. Selected benzimidazoles appeared to be more potent (up to ca. 20-fold) toward Rio1 than the first identified inhibitor of Rio1, toyocamycin $\left(\mathrm{IC}_{50}=3.66 \mu \mathrm{M}, K_{i}=2.068 \mu \mathrm{M}\right)$, or 20 - to 120 -fold stronger in comparison to the recently developed Rio1 probes - pyridine caffeic acid benzyl amides (CABA) ( $\mathrm{IC}_{50}$ from 3.8 to $23.7 \mu \mathrm{M}$ ). Thus, derivatives of halogenated benzimidazoles may constitute a novel class of inhibitors of protein kinase Rio1 [25, 26].

In order to make complete representation of the link between Rio1 and CK2, two reference compounds toyocamycin and CX-4945 were also used [25, 40]. Protein kinase $\mathrm{CK} 2$ was quite refractory $\left(\mathrm{IC}_{50}=55 \mu \mathrm{M}\right.$, $\left.K_{i}=23.48 \mu \mathrm{M}\right)$ to toyocamycin, the first small-molecule inhibitor of kinase Rio1, while the atypical kinase showed sensitivity $\left(\mathrm{IC}_{50}=0.37 \mu \mathrm{M}, \quad K_{i}=0.209 \mu \mathrm{M}\right)$ towards CX-4945-the most potent inhibitor of the protein kinase CK2, currently being in clinical trials. Although the nanomolar range of the $\mathrm{IC}_{50}$ value may suggest intriguing potency of CX-4945 towards Rio1, the compound is a much more potent inhibitor of several other kinases, with CK2 on the top [40-42].

\section{TIBI as an ATP-competitive inhibitor of Rio1, and its influence on oligomerization of the enzyme}

In order to determine whether the well-known ATP-competitive inhibitors of protein kinase CK2 act in the same mode towards Rio1, we determined the steady-state kinetic parameters for the kinase ( $K_{\mathrm{m}}$ for ATP and $V_{\max }$ of Rio1) in the presence and absence of TIBI. To calculate these parameters, the assay of Rio1 autophosphorylation reaction was used and the level of phosphate (P-32) incorporated into Rio1 was measured. We observed that $K_{\mathrm{m}}$ for ATP began to rise with increasing TIBI concentrations, starting with $0.65 \mu \mathrm{M}$ (at $0 \mu \mathrm{M}$ TIBI - control) to $1.07 \mu \mathrm{M}$ at $100 \mu \mathrm{M}$ TIBI (Fig. 1a). Simultaneously, we did not notice any shift in the $V_{\max }$ value remaining at the same level of $0.09 \mathrm{pmol} / \mathrm{sec}$ with the increasing TIBI concentration. To confirm the ATP-competitive nature of the TIBI action, we measured the $\mathrm{IC}_{50}$ values of TIBI for three different ATP concentrations. As expected, the parameter showed a dependence of the ATP content; IC $_{50}$ for TIBI increased with the increasing ATP concentrations as follows: 46, 61, and $101 \mathrm{nM}$ at $0.01,0.1$, and $1 \mu \mathrm{M}$ of ATP, respectively (Fig. 1b). Such low ATP concentrations used in this experiment result from the sensitivity of the kinase Rio1 to

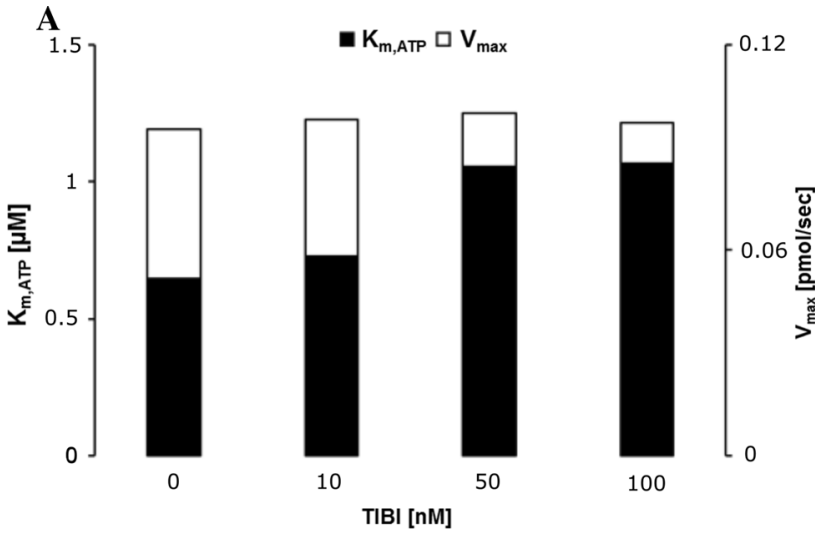

B

\begin{tabular}{cc}
\hline ATP $[\boldsymbol{\mu M}]$ & $\mathrm{IC}_{50}[\mathrm{nM}]$ \\
\hline 0.01 & 46 \\
0.1 & 61 \\
1 & 101 \\
\hline
\end{tabular}

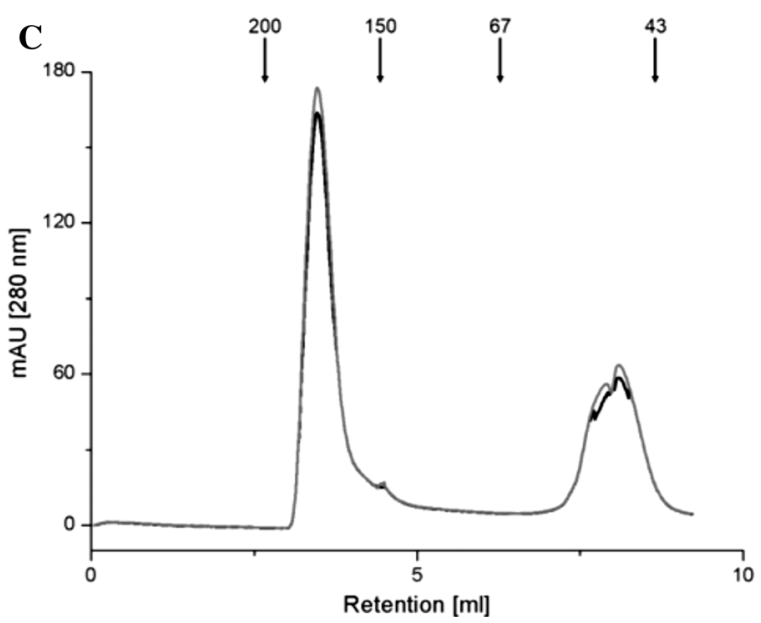

Fig. 1 Steady-state analyses of Rio1. a $K_{\mathrm{m}}$ for ATP and $V_{\max }$ of Rio1 at the increasing concentration of TIBI. $\mathbf{b} \mathrm{IC}_{50}$ determinations for TIBI against Rio1 at different ATP concentrations. c Size-exclusion chromatography plots for Rio1 with (black line) and without (grey line) TIBI. The positions of molecular weight standards $(\mathrm{kDa})$ are indicated with arrows 
ATP concentration higher than $1 \mu \mathrm{M}[25,26]$. Since the results obtained correspond to the linear relationship between $\mathrm{IC}_{50}$ and ATP described in the Cheng and Prusoff equation, TIBI and most probably the other tested benzimidazoles act as strict ATP-competitive inhibitors of the atypical kinase Rio1 [43].

Based on the data from the size-exclusion chromatography, we observed that human Rio1 (aa 134-494) can exist in two isoforms, i.e. a monomer ( $49 \mathrm{kDa})$ and a dominant tetramer (185 kDa) (Fig. 1c). Similar observation by Kiburu and LaRonde revealed that unphosphorylated human and archaeal Riol forms higher order oligomers, while phosphorylation promotes monomerization [25]. In contrast to the recently evaluated inhibitors of the Rio1 kinase (toyocamycin, CABA), TIBI seems not to function as an allosteric inhibitor of Riol promoting less active oligomeric states of the kinase [26]. In the case of hRio1 treated with TIBI, we did not observe any changes in the monomer-tetramer equilibrium, compared with the intact enzyme. This observation is consistent with the kinetic data indicating an ATP-competitive mode of TIBI and thus benzimidazole action in Riol inhibition.

\section{TIBI can occupy the ATP-binding site and enhances the thermostability of protein kinase Rio1}

In order to rationalize the biological results discussed above, docking studies were performed with the TIBI compound and toyocamycin. The docking calculations of TIBI and Rio1 rendered a common pose for the benzotriazole moiety within the ATP-binding site in kinase CK2 described in resolved crystal structures (Fig. 2b) [30]. The main core of the inhibitor is lodged deep in the binding pocket establishing Van der Waals interactions with the side chains of Leu331, Ile340, Ile186, Val194, Ile280, Pro286, Pro265, Ala206, and Met277 within the adenine-binding site. In turn, the diazole ring is oriented towards the hydrophilic area composed of side chains of Lys208, Glu250, and Asp341. Similar results were obtained for toyocamycin. The main adenosine ring occupies the same space as the benzotriazole ring of TIBI, while the charged sugar ring faces the bulk solvent at the entrance to the ATP-binding pocket, where the side chains of Ser287, Asp341, and Ans329 are located (Fig. 2a).

The thermal shift assay revealed that TIBI-the novel benzimidazole inhibitor of human Rio1-significantly enhanced the thermostability of the kinase (Fig. 3a). We observed a shift of $10{ }^{\circ} \mathrm{C}$ in the melting temperature $\left(T_{\mathrm{m}}\right)$ of bound Riol $\left(68.8^{\circ} \mathrm{C}\right)$ in comparison to the unbound enzyme $\left(58.8^{\circ} \mathrm{C}\right)$. The results obtained correspond to data presented by Kiburu and LaRonde, who reported a shift of $12.1{ }^{\circ} \mathrm{C}$ in $T_{\mathrm{m}}$ in the case of the human Rio1 bound to
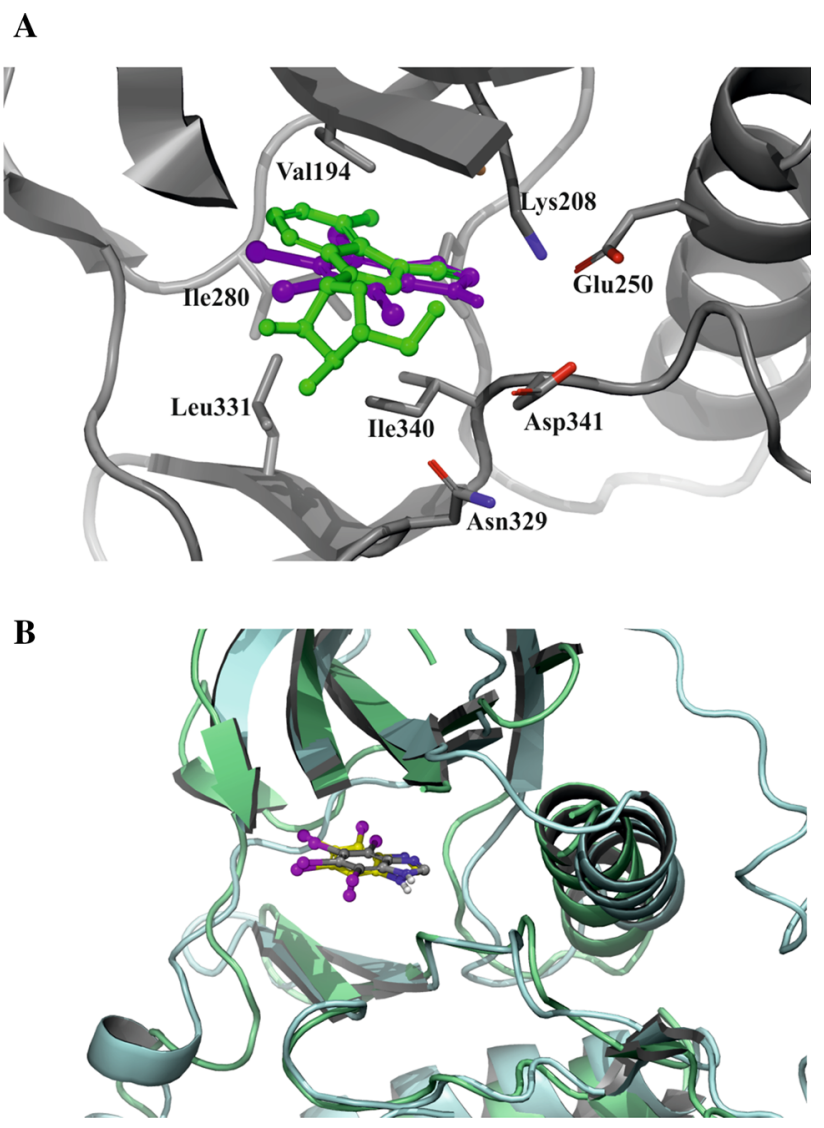

Fig. 2 Docked binding mode obtained with Autodock Vina for a TIBI (purple) and toyocamycin (green) in Rio1, b TIBI in Rio1 (yellow carbons and green cartoon) and CK2 (grey carbons and aquamarine cartoon). (Color figure online)

toyocamycin [25]. Simultaneously, we compared the Rio1 with CK2 with respect to the TIBI-mediated changes in the thermostability of proteins. On the one hand, as it is described above, TIBI shows similar potency towards $\mathrm{CK} 2 \alpha$ and Rio1, which reflects the $\mathrm{IC}_{50}$ values, i.e. 0.083 and $0.09 \mu \mathrm{M}$, respectively. On the other hand, a shift of $20{ }^{\circ} \mathrm{C}$ in the melting temperature $\left(T_{\mathrm{m}}\right)$ of TIBI-bound $\mathrm{CK} 2 \alpha\left(78.8^{\circ} \mathrm{C}\right)$ in comparison to the unbound enzyme $\left(58.8{ }^{\circ} \mathrm{C}\right)$ was observed (Fig. 3b). Thus, TIBI when bound to $\mathrm{CK} 2 \alpha$ stabilizes structure of the enzyme to a greater degree than in the case of Riol.

\section{The link between atypical kinase Rio1 and CK2}

Our results provide another relationship between the two kinases. CK2-mediated phosphorylation of yeast Rio1 and its influence on upregulation of the enzyme were reported [44]. The authors showed that Rio1 interacts preferentially with $\mathrm{CK} 2 \alpha^{\text {* }}$ and phosphorylation of Rio1 promotes cell proliferation. Thus, the similar susceptibility of the two kinases to benzimidazoles creates another cross-link between the enzymes, and creates an additional condition 

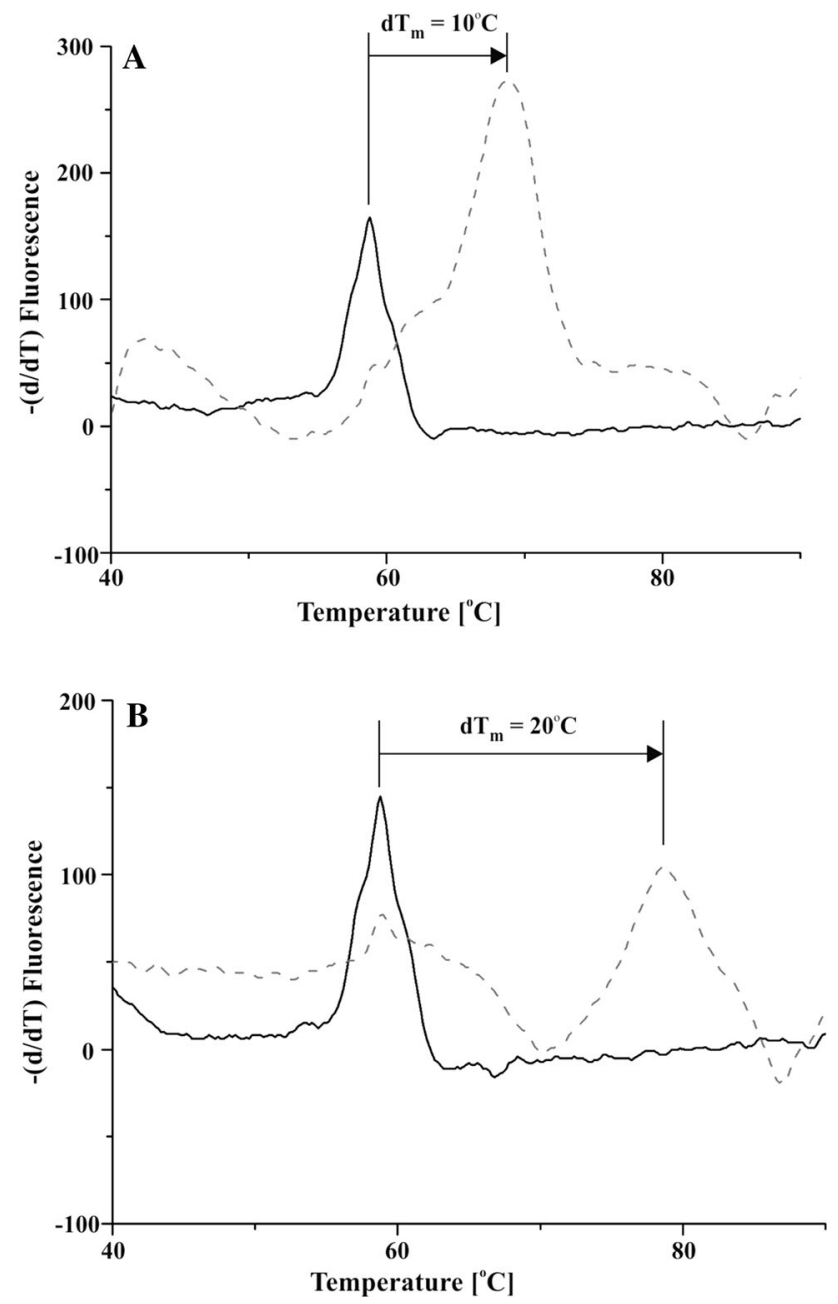

Fig. 3 Melt curve derivative plots for a Rio1 and b CK2. Protein kinases were analysed using thermal shift assays in the absence (solid lines) and presence (dashed lines) of TIBI. The shifts in $T_{\mathrm{m}}$ are indicated with black arrows

for designing novel benzimidazole-based inhibitors of CK2.

Although it is widely reported that halogenated benzimidazoles inhibit protein kinase CK2 and induce apoptosis, the molecular mechanism by which these chemicals function in cells has not been systematically explored. Duncan and coworkers revealed that structurally related TBB, TBI, and DMAT had unique biological properties, suggesting differences in inhibitor specificity [45]. Our results suggest that proapoptotic benzimidazoles may, among many other cellular events, cause disturbances in Rio1 activity and, consequently, in ribosome biogenesis, and these events may contribute to benzimidazole-mediated programmed cell death. Koronkiewicz and coworkers showed proapoptotic activity of TIBI in the promyelocytic leukemia cell line HL-60 [39]. Taking the above into consideration, the promising findings presented here need to be extended with the use of cell lines in order to assess the influence of TIBI on endogenous Rio1.

Open Access This article is distributed under the terms of the Creative Commons Attribution 4.0 International License (http://crea tivecommons.org/licenses/by/4.0/), which permits unrestricted use, distribution, and reproduction in any medium, provided you give appropriate credit to the original author(s) and the source, provide a link to the Creative Commons license, and indicate if changes were made.

\section{References}

1. Hafen E (1998) Kinases and phosphatases-a marriage is consummated. Science 280:1212-1213

2. Cohen $P$ (2002) The origins of protein phosphorylation. Nat Cell Biol 4:E127-E130. doi:10.1038/ncb0502-e127

3. Manning G, Whyte DB, Martinez R, Hunter T, Sudarsanam S (2002) The protein kinase complement of the human genome. Science 298:1912-1934. doi:10.1126/science.1075762

4. Blume-Jensen P, Hunter T (2001) Oncogenic kinase signalling. Nature 411:355-365. doi:10.1038/35077225

5. Brognard J, Hunter T (2011) Protein kinase signaling networks in cancer. Curr Opin Genet Dev 21:4-11. doi:10.1016/j.gde.2010. 10.012

6. Meggio F, Pinna LA (2003) One-thousand-and-one substrates of protein kinase CK2? FASEB J 17:349-368. doi:10.1096/fj.020473rev

7. Olsten ME, Litchfield DW (2004) Order or chaos? An evaluation of the regulation of protein kinase CK2. Biochem Cell Biol 82:681-693. doi:10.1139/004-116

8. Litchfield DW (2003) Protein kinase CK2: structure, regulation and role in cellular decisions of life and death. Biochem $\mathrm{J}$ 369:1-15. doi:10.1042/BJ20021469

9. St-Denis NA, Litchfield DW (2009) Protein kinase CK2 in health and disease: from birth to death: the role of protein kinase CK2 in the regulation of cell proliferation and survival. Cell Mol Life Sci 66:1817-1829. doi:10.1007/s00018-009-9150-2

10. Cozza G, Bortolato A, Moro S (2010) How druggable is protein kinase CK2? Med Res Rev 30:419-462. doi:10.1002/med.20164

11. Zandomeni R, Zandomeni MC, Shugar D, Weinmann R (1986) Casein kinase type II is involved in the inhibition by 5,6-dichloro1-beta-D-ribofuranosylbenzimidazole of specific RNA polymerase II transcription. J Biol Chem 261:3414-3419

12. Pagano MA, Andrzejewska M, Ruzzene M, Sarno S, Cesaro L, Bain J, Elliott M, Meggio F, Kazimierczuk Z, Pinna LA (2004) Optimization of protein kinase CK2 inhibitors derived from 4,5,6,7-tetrabromobenzimidazole. J Med Chem 47:6239-6247. doi:10.1021/jm049854a

13. Pagano MA, Bain J, Kazimierczuk Z, Sarno S, Ruzzene M, Di Maira G, Elliott M, Orzeszko A, Cozza G, Meggio F, Pinna LA (2008) The selectivity of inhibitors of protein kinase CK2: an update. Biochem J 415:353-365. doi:10.1042/BJ20080309

14. Pagano MA, Meggio F, Ruzzene M, Andrzejewska M, Kazimierczuk Z, Pinna LA (2004) 2-Dimethylamino-4,5,6,7-tetrabromo-1H-benzimidazole: a novel powerful and selective inhibitor of protein kinase CK2. Biochem Biophys Res Commun 321:1040-1044. doi:10.1016/j.bbrc.2004.07.067

15. Hessenauer A, Schneider CC, Götz C, Montenarh M (2011) CK2 inhibition induces apoptosis via the ER stress response. Cell Signal 23:145-151. doi:10.1016/j.cellsig.2010.08.014

16. Angermayr M, Bandlow W (2002) RIO1, an extraordinary novel protein kinase. FEBS Lett 524:31-36 
17. LaRonde NA (2014) The ancient microbial RIO kinases. J Biol Chem 289:9488-9492. doi:10.1074/jbc.R113.538090

18. Vanrobays E, Gelugne JP, Gleizes PE, Caizergues-Ferrer M (2003) Late cytoplasmic maturation of the small ribosomal subunit requires RIO proteins in Saccharomyces cerevisiae. Mol Cell Biol 23:2083-2095

19. Ferreira-Cerca S, Kiburu I, Thomson E, LaRonde N, Hurt E (2014) Dominant Rio1 kinase/ATPase catalytic mutant induces trapping of late pre-40S biogenesis factors in 80S-like ribosomes. Nucleic Acids Res 42:8635-8647. doi:10.1093/nar/gku542

20. Iacovella MG, Golfieri C, Massari LF, Busnelli S, Pagliuca C, Dal Maschio M, Infantino V, Visintin R, Mechtler K, FerreiraCerca S, De Wulf P (2015) Rio1 promotes rDNA stability and downregulates RNA polymerase I to ensure rDNA segregation. Nat Commun 6:6643. doi:10.1038/ncomms7643

21. Angermayr M, Roidl A, Bandlow W (2002) Yeast Riolp is the founding member of a novel subfamily of protein serine kinases involved in the control of cell cycle progression. Mol Microbiol 44:309-324

22. Turowski TW, Lebaron S, Zhang E, Peil L, Dudnakova T, Petfalski E, Granneman S, Rappsilber J, Tollervey D (2014) Rio1 mediates ATP-dependent final maturation of 40S ribosomal subunits. Nucleic Acid Res 42:12189-12199. doi:10.1093/nar/ gku878

23. Ruggero D, Pandolfi PP (2003) Does the ribosome translate cancer? Nat Rev Cancer 3:179-192. doi:10.1038/nrc1015

24. Read RD, Fenton TR, Gomez GG, Wykosky J, Vandenberg SR, Babic I, Iwanami A, Yang H, Cavenee WK, Mischel PS, Furnari FB, Thomas JB (2013) A kinome-wide RNAi screen in Drosophila Glia reveals that the RIO kinases mediate cell proliferation and survival through TORC2-Akt signaling in glioblastoma. PLoS Genet 9:e1003253. doi:10.1371/journal.pgen.1003253

25. Kiburu IN, LaRonde-LeBlanc N (2012) Interaction of Rio1 kinase with toyocamycin reveals a conformational switch that controls oligomeric state and catalytic activity. PLoS ONE 7:e37371. doi:10.1371/journal.pone.0037371

26. Mielecki M, Krawiec K, Kiburu I, Grzelak K, Zagórski W, Kierdaszuk B, Kowa K, Fokt I, Szymanski S, Swierk P, Szeja W, Priebe W, Lesyng B, LaRonde-LeBlanc N (2013) Development of novel molecular probes of the Riol atypical protein kinase. Biochim Biophys Acta 1834:1292-1301. doi:10.1016/j.bbapap. 2013.03.012

27. Gianoncelli A, Cozza G, Orzeszko A, Meggio F, Kazimierczuk Z, Pinna LA (2009) Tetraiodobenzimidazoles are potent inhibitors of protein kinase CK2. Bioorg Med Chem 17:7281-7289. doi:10.1016/j.bmc.2009.08.047

28. Schneider CC, Kartarius S, Montenarh M, Orzeszko A, Kazimierczuk Z (2012) Modified tetrahalogenated benzimidazoles with CK2 inhibitory activity are active against human prostate cancer cells LNCaP in vitro. Bioorg Med Chem 20:4390-4396. doi:10.1016/j.bmc.2012.05.038

29. Andrzejewska M, Pagano MA, Meggio F, Brunati AM, Kazimierczuk Z (2003) Polyhalogenobenzimidazoles: synthesis and their inhibitory activity against casein kinases. Bioorg Med Chem 11:3997-4002

30. Sarno S, Papinutto E, Franchin C, Bain J, Elliott M, Meggio F, Kazimierczuk Z, Orzeszko A, Zanotti G, Battistutta R, Pinna LA (2011) ATP site-directed inhibitors of protein kinase CK2: an update. Curr Top Med Chem 11:1340-1351

31. Janeczko M, Orzeszko A, Kazimierczuk Z, Szyszka R, Baier A (2012) CK2 $\alpha$ and CK2 $\alpha$ ' subunits differ in their sensitivity to 4,5,6,7-tetrabromo- and 4,5,6,7-tetraiodo-1H-benzimidazole derivatives. Eur J Med Chem 47:345-350. doi:10.1016/j.ejmech. 2011.11.002

32. Fraczyk T, Kubiński K, Masłyk M, Cieśla J, Hellman U, Shugar D, Rode W (2010) Phosphorylation of thymidylate synthase from various sources by human protein kinase CK2 and its catalytic subunits. Bioorg Chem 38:124-131. doi:10.1016/j.bioorg.2010. 02.001

33. LaRonde-LeBlanc N, Guszczynski T, Copeland T, Wlodawer A (2005) Autophosphorylation of Archaeoglobus fulgidus Rio2 and crystal structures of its nucleotide-metal ion complexes. FEBS J 272:2800-2810. doi:10.1111/j.1742-4658.2005.04702.x

34. Krieger E, Joo K, Lee J, Raman S, Thompson J, Tyka M, Baker D, Karplus K (2009) Improving physical realism, stereochemistry, and side-chain accuracy in homology modeling: four approaches that performed well in CASP8. Proteins 77(Suppl 9):114-122. doi:10.1002/prot.22570

35. Trott O, Olson AJ (2010) AutoDock Vina: improving the speed and accuracy of docking with a new scoring function, efficient optimization, and multithreading. J Comput Chem 31:455-461. doi:10.1002/jcc.21334

36. Zień P, Bretner M, Zastapiło K, Szyszka R, Shugar D (2003) Selectivity of 4,5,6,7-tetrabromobenzimidazole as an ATP-competitive potent inhibitor of protein kinase CK2 from various sources. Biochem Biophys Res Commun 306:129-133

37. Zień P, Abramczyk O, Domańska K, Bretner M, Szyszka R (2003) TBBz but not TBBt discriminates between two molecular forms of CK2 in vivo and its implications. Biochem Biophys Res Commun 312:623-628. doi:10.1016/j.bbrc.2003.10.165

38. Zien P, Duncan JS, Skierski J, Bretner M, Litchfield DW, Shugar D (2005) Tetrabromobenzotriazole (TBBt) and tetrabromobenzimidazole (TBBz) as selective inhibitors of protein kinase CK2: evaluation of their effects on cells and different molecular forms of human CK2. Biochim Biophys Acta 1754:271-280. doi:10. 1016/j.bbapap.2005.07.039

39. Koronkiewicz M, Zukowska M, Chilmonczyk Z, Orzeszko A, Kazimierczuk Z (2010) Synthesis and proapoptotic properties of new casein kinase II inhibitors. Acta Pol Pharm 67:635-641

40. Siddiqui-Jain A, Drygin D, Streiner N, Chua P, Pierre F, O'Brien SE, Bliesath J, Omori M, Huser N, Ho C, Proffitt C, Schwaebe MK, Ryckman DM, Rice WG, Anderes K (2010) CX-4945, an orally bioavailable selective inhibitor of protein kinase CK2, inhibits prosurvival and angiogenic signaling and exhibits antitumor efficacy. Cancer Res 70:10288-10298. doi:10.1158/00085472.CAN-10-1893

41. Kim J, Kim SH (2012) Druggability of the CK2 inhibitor CX4945 as an anticancer drug and beyond. Arch Pharm Res 35:1293-1296. doi:10.1007/s12272-012-0800-9

42. Pierre F, Chua PC, O'Brien SE, Siddiqui-Jain A, Bourbon P, Haddach M, Michaux J, Nagasawa J, Schwaebe MK, Stefan E, Vialettes A, Whitten JP, Chen TK, Darjania L, Stansfield R, Bliesath J, Drygin D, Ho C, Omori M, Proffitt C, Streiner N, Rice WG, Ryckman DM, Anderes K (2011) Pre-clinical characterization of CX-4945, a potent and selective small molecule inhibitor of CK2 for the treatment of cancer. Mol Cell Biochem 356:37-43. doi:10.1007/s11010-011-0956-5

43. Cheng Y, Prusoff WH (1973) Relationship between the inhibition constant (K1) and the concentration of inhibitor which causes 50 per cent inhibition (I50) of an enzymatic reaction. Biochem Pharmacol 22:3099-3108

44. Angermayr M, Hochleitner E, Lottspeich F, Bandlow W (2007) Protein kinase CK2 activates the atypical Riolp kinase and promotes its cell-cycle phase-dependent degradation in yeast. FEBS J 274:4654-4667. doi:10.1111/j.1742-4658.2007.05993.x

45. Duncan JS, Gyenis L, Lenehan J, Bretner M, Graves LM, Haystead TA, Litchfield DW (2008) An unbiased evaluation of CK2 inhibitors by chemoproteomics: characterization of inhibitor effects on CK2 and identification of novel inhibitor targets. Mol Cell Proteom 7:1077-1088. doi:10.1074/mcp.M700559-MCP200 